\title{
Inclusion of wheat and triticale silage in the diet of lactating dairy cows
}

\author{
M. T. Harper, ${ }^{*}$ J. Oh, ${ }^{*}$ F. Giallongo, ${ }^{*}$ G. W. Roth, $\dagger$ and A. N. Hristov ${ }^{* 1}$ \\ *Department of Animal Science, and \\ †Department of Plant Science, The Pennsylvania State University, University Park 16802
}

\section{ABSTRACT}

The objective of this experiment was to partially replace corn silage with 2 alternative forages, wheat (Triticum aestivum) or triticale (X Triticosecale) silages at $10 \%$ of the diet dry matter (DM), and investigate the effects on dairy cow productivity, nutrient utilization, enteric $\mathrm{CH}_{4}$ emissions, and farm income over feed costs. Wheat and triticale were planted in the fall as cover crops and harvested in the spring at the boot stage. Neutral- and acid-detergent fiber and lignin concentrations were higher in the wheat and triticale silages compared with corn silage. The forages had similar ruminal in situ effective degradability of DM. Both alternative forages had $1 \%$ starch or less compared with the approximately $35 \%$ starch in corn silage. Diets with the alternative forages were fed in a replicated $3 \times 3$ Latin square design experiment with three 28 -d periods and 12 Holstein cows. The control diet contained 44\% (DM basis) corn silage. In the other 2 diets, wheat or triticale silages were included at $10 \%$ of dietary DM, replacing corn silage. Dry matter intake was not affected by diet, but both wheat and triticale silage decreased yield of milk (41.4 and 41.2 vs. $42.7 \pm 5.18 \mathrm{~kg} / \mathrm{d}$ ) and milk components, compared with corn silage. Milk fat from cows fed the alternative forage diets contained higher concentrations of 4:0, 6:0, and 18:0 and tended to have lower concentrations of total trans fatty acids. Apparent total-tract digestibility of DM and organic matter was decreased in the wheat silage diet, and digestibility of neutral-and acid-detergent fiber was increased in the triticale silage diet. The wheat and triticale silage diets resulted in higher excretion of urinary urea, higher milk urea $\mathrm{N}$, and lower milk $\mathrm{N}$ efficiency compared with the corn silage diet. Enteric $\mathrm{CH}_{4}$ emission per kilogram of energy-corrected milk was highest in the triticale silage diet, whereas $\mathrm{CO}_{2}$ emission was decreased by both wheat and triticale silage. This study showed that, at milk production of around $42 \mathrm{~kg} / \mathrm{d}$, wheat silage and triticale silage can partially replace corn silage DM

Received January 4, 2017.

Accepted April 11, 2017.

${ }^{1}$ Corresponding author: anh13@psu.edu and not affect DM intake, but milk yield may decrease slightly. For dairy farms in need of more forage, triticale or wheat double cropped with corn silage may be an appropriate cropping strategy.

Key words: dairy cow, forage, triticale silage, wheat silage

\section{INTRODUCTION}

Dairies in the northeastern United States typically grow their own forages. The most used forage, corn silage, leaves bare soil after fall harvesting until spring planting. Cover crops, such as small grains and clovers, have been used to prevent soil erosion during bare soil periods. Preserving the soil is critically important for continued crop productivity, and therefore has long-term benefits. Cover crops have the potential to efficiently use fall-applied manure and reduce nitrate leaching (Shepherd, 1999; Di and Cameron, 2002; Carey et al., 2016); however, planting a cover crop requires a short-term investment of labor, equipment, and other inputs. The use of cover crops as an alternative forage has increased in popularity as a way to offset planting costs, increase the annual forage yield per acre, and thereby harvest more forage from the same land base. Recent plot studies conducted at The Pennsylvania State University showed a 4.5 to $6.5 \mathrm{t}$ of DM/ha average annual forage yield increase when double cropping corn silage with rye or triticale cover crop harvested as silage in the flag leaf stage (G. W. Roth, The Pennsylvania State University, University Park, PA, personal communication). However, the corn silage portion of annual forage yields typically decrease between 10 and 20\%, depending on planting date, under double-cropping management due to delayed planting (PSU, 2015). Less corn silage inventory leads to the question: Can cover crop silages replace a portion of corn silage in dairy cattle diets? Several studies in the United Kingdom have reported similar milk yield (MY) responses to corn or wheat silages harvested after kernel development (Hameleers, 1998; Sinclair et al., 2005). In those studies, however, the wheat silage contained higher starch concentrations than the corn silage. In Canada, Khorasani et al. (1993) compared 
cereal grain silages, including triticale, to alfalfa haylage; they reported a decrease in DMI for triticale silage but no significant difference in MY, and suggested that triticale silage could be used in dairy cow rations. The dough stage harvest schedule increases starch content but delays harvest past the planting window for corn in the northeast United States, and, as such, cannot be used with corn silage double cropping. Harvesting cereal crops at the boot stage yields similar NDF content to the dough stage (Khorasani et al., 1997), but with increased NDF digestibility (Arieli and Adin, 1994). Additionally, at the flag leaf or boot stages, cereal crops can have CP concentrations above $12 \%$ (Fearon et al., 1990; Ashbell et al., 1997; Crovetto et al., 1998). Wheat and triticale are 2 cereal grain cover crops suited to the northeast United States that are used as lactating dairy cow forage in other areas of the world. Furthermore, both forages grow well in cool weather and survive cold winters.

Therefore, we hypothesized that both wheat and triticale, when harvested in the boot stage, could serve as alternative forages to augment corn silage use in lactating dairy cow rations in the northeastern United States. The objective of the experiment was to replace corn silage with either triticale silage or wheat silage at $10 \%$ of the diet DM and investigate the effects on DMI, MY, milk components and fatty acid (FA) profile, nutrient digestibility, $\mathrm{N}$ utilization, enteric $\mathrm{CH}_{4}$ emissions, and income over feed costs (IOFC) in lactating dairy cows.

\section{MATERIALS AND METHODS}

\section{Crops and Silages}

Wheat (Triticum aestivum L. 'Malabar'; King's Agriseeds, Ronks, PA) and triticale (X Triticosecale L. 'Hyoctane'; Seedway, Hall, NY) were grown in Centre County, Pennsylvania, at approximately $40^{\circ} \mathrm{N}$ latitude on Hagerstown and Hublersburg soils during the fall of 2014. Both crops were planted with a no-till drill (John Deere 1590, Moline, IL) into fields fertilized with 44.8 t/ha of dairy manure before planting, contributing 42 $\mathrm{kg} / \mathrm{ha}$ of ammonium N. Forages were planted next to each other in the same field with 19-cm row spacing on October 10, 2014, after wheat harvested for grain. Seeding rate was $151 \mathrm{~kg} /$ ha for triticale and wheat. On April 4, 2015, both wheat and triticale were fertilized with $67 \mathrm{~kg}$ of $\mathrm{N} / \mathrm{ha}$ from a $30 \%$ urea and ammonium nitrate liquid fertilizer. A John Deere 946 mower with a roll conditioner was used to mow both crops and, after wilting to target $30 \% \mathrm{DM}$, the forages were gathered and chopped using a John Deere 6750 harvester. Mowing was conducted on May 13 and 19, 2015, at the boot stage for triticale and wheat, respectively, and chopping occurred on May 15 and 20, respectively. Chop length was set to $12 \mathrm{~mm}$. Both crops were ensiled without inoculant in 3-m diameter plastic silage bags (Up North Plastics, Cottage Grove, MN). The corn silage, which was the control in this experiment, was a mixture of hybrids, including Mycogen TMF2R737 (112-d relative maturity; Mycogen, San Diego, CA), Dekalb DKC 5261 (102-d relative maturity; DeKalb, St. Louis, MO), and NK N60F-3111 (107-d relative maturity; Syngenta, Basel, Switzerland). Corn silage was grown in Centre County, Pennsylvania, at approximately $40^{\circ} \mathrm{N}$ latitude on Hagerstown and Hublersburg soils and planted between May 1 and May 10, 2014, at a rate of 79,000 seeds/ha. It was planted with a no-till drill (John Deere 1590) into fields fertilized with $45 \mathrm{t} / \mathrm{ha}$ of dairy manure before planting contributing $42 \mathrm{~kg} /$ ha of ammonium $\mathrm{N}$. An additional $43 \mathrm{~kg} / \mathrm{ha}$ of $\mathrm{N}$ was applied as $30 \%$ urea and ammonium nitrate liquid before planting, and 67 $\mathrm{kg} / \mathrm{ha}$ of $\mathrm{N}$ in the same form as a side-dress application. Corn silage harvest was conducted between September 15 and 30,2014 , at a target DM of $38 \%$ with a 19$\mathrm{mm}$ chop length; corn silage was ensiled in an upright concrete silo.

\section{Animals and Diets}

All animals were cared for according to procedures approved by The Pennsylvania State University's Institutional Animal Care and Use Committee. Twelve mid-lactation Holstein dairy cows (MY $=42 \pm 10.1$ $\mathrm{kg} ; 2.5 \pm 1.38$ lactations; DIM $=38 \pm 5.7 ; \mathrm{BW}=632$ $\pm 101.6 \mathrm{~kg}$ at the beginning of the experiment) were used in a replicated $3 \times 3$ Latin square design balanced for residual effects. The experiment had 3 periods and each period was $28 \mathrm{~d}$, with $18 \mathrm{~d}$ for adaptation to the diet and $10 \mathrm{~d}$ for data and sample collection. Cows were allocated to 4 groups of 3 cows each based on DIM, MY, and parity. Cows within a group were randomly assigned to 1 of 3 diets, as described below. All cows were housed in the tiestall barn of The Pennsylvania State University's Dairy Research and Teaching Center (University Park). Diets were mixed and fed from a Rissler model 1050 TMR mixer (I.H. Rissler Mfg. LLC, Mohnton, PA). Cows were fed once daily around 0800 $\mathrm{h}$ to yield approximately 5 to $10 \%$ refusals. Feed was pushed up 3 times throughout the day. The cows were milked twice daily at 0700 and $1800 \mathrm{~h}$.

Three different diets (Table 1), were fed to the cows during the experiment: a control diet (CS), based on corn silage and alfalfa haylage; a triticale silage diet (TS), triticale silage included at $10 \%$ of dietary DM, replacing $22.7 \%$ of the control diet corn silage DM; and a wheat silage diet (WS), wheat silage included at $10 \%$ of dietary DM, replacing $22.7 \%$ of the control diet corn 
silage DM. The only difference between the control and alternative forage diets was the replacement of $22.7 \%$ corn silage DM with either wheat or triticale silage. The CS diet was formulated to meet or exceed the NRC (2001) $\mathrm{NE}_{\mathrm{L}}$ and MP requirements of a Holstein cow with $680 \mathrm{~kg}$ of BW, $41.7 \mathrm{~kg} / \mathrm{d}$ of MY, $3.8 \%$ fat, $3.2 \%$ true protein, and at $26.3 \mathrm{~kg} / \mathrm{d}$ of DMI.

Table 1. Ingredient and chemical composition of the diets fed in the experiment

\begin{tabular}{|c|c|c|c|}
\hline \multirow[b]{2}{*}{ Item } & \multicolumn{3}{|c|}{$\operatorname{Diet}^{1}$} \\
\hline & $\mathrm{CS}$ & TS & WS \\
\hline \multicolumn{4}{|l|}{ Ingredient, $\%$ of DM } \\
\hline Corn silage $^{2}$ & 44 & 34 & 34 \\
\hline Alfalfa haylage $^{3}$ & 8 & 8 & 8 \\
\hline Triticale silage & - & 10 & - \\
\hline Wheat silage & - & - & 10 \\
\hline Hay/straw mixture & 5 & 5 & 5 \\
\hline Cottonseed hulls & 4 & 4 & 4 \\
\hline Ground corn & 9 & 9 & 9 \\
\hline Heat-treated whole soybeans & 7.5 & 7.5 & 7.5 \\
\hline Solvent-extracted canola meal & 8 & 8 & 8 \\
\hline SoyPLUS ${ }^{4}$ & 7 & 7 & 7 \\
\hline Molasses $^{5}$ & 4.5 & 4.5 & 4.5 \\
\hline Mineral/vitamin premix $^{6}$ & 3 & 3 & 3 \\
\hline \multicolumn{4}{|l|}{ Composition, \% of DM } \\
\hline $\mathrm{CP}^{7}$ & 16.1 & 17.2 & 16.9 \\
\hline $\mathrm{RDP}^{8}$ & 9.7 & 10.4 & 10.0 \\
\hline RUP $^{8}$ & 6.4 & 6.8 & 6.9 \\
\hline $\mathrm{NDF}^{7}$ & $\begin{array}{r}0.4 \\
33.5\end{array}$ & 34.5 & 34.5 \\
\hline $\mathrm{iNDF}^{9}$ & 12.0 & 11.7 & 12.8 \\
\hline $\mathrm{ADF}^{7}$ & 21.7 & 22.6 & 22.5 \\
\hline $\mathrm{NFC}^{8}$ & 43.1 & 40.3 & 40.8 \\
\hline Starch ${ }^{7}$ & 22.7 & 19.3 & 19.3 \\
\hline $\mathrm{Fat}^{7}$ & 4.9 & 4.9 & $\begin{array}{r}10.0 \\
4.9\end{array}$ \\
\hline $\mathrm{NE}_{\mathrm{L}},{ }^{8} \mathrm{Mcal} / \mathrm{kg}$ & 1.56 & 1.57 & 1.55 \\
\hline $\mathrm{NE}_{\mathrm{L}}$ intake, ${ }^{8} \mathrm{Mcal} / \mathrm{d}$ & 42.5 & 43.6 & 42.7 \\
\hline $\mathrm{NE}_{\mathrm{L}}$ balance, ${ }^{8} \mathrm{Mcal} / \mathrm{d}$ & 1.7 & 3.5 & 3.2 \\
\hline $\mathrm{Ash}^{7}$ & 6.7 & 7.3 & 7.2 \\
\hline $\mathrm{Ca}^{7}$ & 0.8 & 0.8 & 0.8 \\
\hline $\mathrm{P}^{7}$ & 0.4 & 0.4 & 0.4 \\
\hline
\end{tabular}

${ }^{1} \mathrm{CS}=$ corn silage control diet; $\mathrm{TS}=$ triticale silage diet; $\mathrm{WS}=$ wheat silage diet.

${ }^{2}$ Corn silage was $38.5 \% \mathrm{DM}$ and contained (DM basis) $6.4 \% \mathrm{CP}, 46.6 \%$ NFC, $34.5 \%$ starch, and $41.0 \%$ NDF.

${ }^{3}$ Alfalfa haylage was $46.0 \% \mathrm{DM}$ and contained (DM basis) $21.0 \% \mathrm{CP}$, $24.0 \%$ NFC, and $44.2 \%$ NDF.

${ }^{4}$ SoyPLUS (West Central Cooperative, Ralston, IA).

${ }^{5}$ Molasses (Westway Feed Products, Tomball, TX).

${ }^{6}$ The mineral/vitamin premix (Cargill Animal Nutrition, Cargill Inc., Roaring Spring, PA) contained (\%, as-is basis, unless noted) trace mineral mix, $0.86 ; \mathrm{MgO}(56 \% \mathrm{Mg}), 8.0 ; \mathrm{NaCl}, 6.4$; vitamin $\mathrm{ADE}$ premix (Cargill Animal Nutrition, Cargill Inc.), 0.48; limestone, 37.2; selenium premix (Cargill Animal Nutrition, Cargill Inc.), 0.07; and dry corn distillers grains with solubles, 46.7; Ca, $14.1 \% ; \mathrm{P}, 0.39 \% ; \mathrm{Mg}$, $4.60 \%$; K, $0.45 \%$; S, $0.38 \%$; Se, $6.67 \mathrm{mg} / \mathrm{kg} ; \mathrm{Cu}, 358 \mathrm{mg} / \mathrm{kg} ; \mathrm{Zn}, 1,085$ $\mathrm{mg} / \mathrm{kg} ; \mathrm{Fe}, 188 \mathrm{mg} / \mathrm{kg}$, vitamin A, 262,656 IU/kg; vitamin D, 65,559 $\mathrm{IU} / \mathrm{kg}$; and vitamin E, 1,974 IU/kg.

${ }^{7}$ Values calculated using the chemical analysis (Cumberland Valley Analytical Services Inc., Maugansville, MD) of individual feed ingredients of the diet.

${ }^{8}$ Estimated based on NRC (2001).

${ }^{9}$ Indigestible NDF determined by $10-\mathrm{d}$ ruminal incubation.

\section{Sampling and Analyses}

Refusals were collected and weighed individually for each cow before the morning feeding to measure daily as-fed intake. Total mixed ration, refusal, and forage (triticale, wheat, alfalfa, and corn silage) samples were collected twice weekly, composited by week and diet (i.e., silage type), stored at $-20^{\circ} \mathrm{C}$, and then oven-dried at $55^{\circ} \mathrm{C}$ for $72 \mathrm{~h}$. The TMR was sampled within $1 \mathrm{~h}$ of feeding. The weekly DM content of the TMR and refusals was used to calculate the individual daily DMI. Concentrate feeds were sampled weekly and stored at $-20^{\circ} \mathrm{C}$ until analysis. Wheat, triticale, corn, and alfalfa silages were ground through a 4-mm screen (for in situ degradability measurements), then, along with TMR samples, were ground through a 1-mm screen in a Wiley mill (Thomas Scientific, Swedesboro, NJ) and composited by period on an equal weight basis. Dried composite samples of sorghum, oat, and corn silages were sent to Cumberland Valley Analytical Services Inc. (CVAS; Maugansville, MD) to be analyzed by wet chemistry methods for CP, amylase-treated NDF, ADF, lignin, fat, soluble protein, starch, ethanol-soluble carbohydrates, ash, and minerals. Fermentation profiles of fresh frozen samples of the corn, wheat, and triticale silages from each period were analyzed by CVAS by wet chemistry for $\mathrm{pH}$, titratable acidity, and lactic, acetic, propionic, butyric, and isobutyric acid concentrations. Concentrate feed samples were ground through a 1-mm screen and composited for the entire experiment. Dried composite concentrate ingredients were analyzed by wet chemistry methods by CVAS for CP, amylase-treated NDF, ADF, fat, starch, ash, and minerals, and estimated $\mathrm{NFC}$ and $\mathrm{NE}_{\mathrm{L}}$. Analytical methods for all analyses conducted by CVAS are available online (http://www. foragelab.com/Resources/Lab-Procedures; accessed Sep. 14, 2016). Concentrations of CP, NDF, ADF, $\mathrm{NFC}, \mathrm{NE}_{\mathrm{L}}$, starch, fat, ash, $\mathrm{Ca}$ and $\mathrm{P}$ in the TMR were calculated based on the individual feed ingredient values and their percent inclusion in the TMR. The diet values for RDP, RUP, and $\mathrm{NE}_{\mathrm{L}}$ balance were calculated based on NRC (2001).

Milk weights were automatically recorded at each milking using the Afimilk system (Kibbutz Afikim, Israel). Milk samples for components and FA analysis were collected on 2 consecutive days (4 consecutive milkings) during wk 4 of each period from the p.m. and a.m. milkings. Milk component samples were collected into tubes containing 2-bromo-2-nitropropane-1,3-diol and analyzed individually by Dairy One Laboratory (Ithaca, NY) for fat, true protein, MUN, and lactose content using infrared spectroscopy (Milkoscan 4000, Foss Electric, Hillerød, Denmark). Milk samples for FA analysis from the 4 milkings for each period and cow 
were collected without preservative and stored chilled at $4^{\circ} \mathrm{C}$ until composited based on milk production. The composited milk samples were centrifuged $(16,000 \times$ $g$ for $15 \mathrm{~min}$ at $4^{\circ} \mathrm{C}$ ), and the milk fat was skimmed off and stored frozen at $-20^{\circ} \mathrm{C}$ until analyzed using the procedure described by Rico and Harvatine (2013). Cows were weighed $2 \mathrm{~d}$ at the beginning and end of the first and second periods with a Tru-test Eziweigh 2 scale (Mineral Wells, TX). During the third experimental period, BW was recorded daily upon exiting the milking parlor using an AfiFarm 3.04E scale system (S.A.E. Afikim, Rehovot, Israel).

During wk 4 of each period, urine and fecal samples were collected for digestibility and $\mathrm{N}$ utilization analyses. Spot urine and fecal samples (approximately 300 $\mathrm{mL}$ and $500 \mathrm{~g}$ per sample, respectively) were collected 8 times over $3 \mathrm{~d}$ at (d 1) 0500, 1200, and $1800 \mathrm{~h},(\mathrm{~d}$ 2) $2400,0900,1500$, and $2100 \mathrm{~h}$, and (d 3) $0300 \mathrm{~h}$ to obtain a representative sample of a 24 -h period. A full description of the urine and fecal sample processing and analyzing can be found in Lee et al. (2012). Briefly, raw urine from each sampling was acidified, diluted, composited by cow and period, and frozen at $-20^{\circ} \mathrm{C}$ for later analysis of allantoin, uric acid, creatinine, urea $\mathrm{N}$, and total N. Allantoin was analyzed following the procedure by Chen et al. (1992). Stanbio Laboratory (Boerne, TX) kits were used to analyze uric acid (Uric Acid Kit 1045), creatinine (Creatinine Kit 420), and urea N (Urea Nitrogen Kit 580). Total N was analyzed in freeze-dried urine samples of approximately $60 \mu \mathrm{L}$ of 1:10 diluted and acidified urine using a Costech ECS $4010 \mathrm{C} / \mathrm{N} / \mathrm{S}$ elemental analyzer (Costech Analytical Technologies Inc., Valencia, CA). Fecal samples were oven-dried at $65^{\circ} \mathrm{C}$, ground through a $1-\mathrm{mm}$ screen in a Wiley mill, and analyzed for DM, OM, CP, starch, NDF, and ADF. A Mixer Mill MM 200 (Retsch GmbH, Haan, Germany) was used to pulverize a 0.5 -g aliquot of fecal sample for $\mathrm{CP}$ analysis $(\mathrm{N} \times 6.25)$ using a Costech ECS 4010 C/N/S elemental analyzer. Starch analysis of fecal $\mathrm{DM}$ for apparent total-tract digestibility was performed using a procedure similar to the method including acetate buffer described by Hall (2009). Briefly, starch was gelatinized with $50 \% \mathrm{NaOH}$, incubated for $16 \mathrm{~h}$ at $55^{\circ} \mathrm{C}$ with acetate buffer and amylase, centrifuged at $21,000 \times g$ for $10 \mathrm{~min}$ at $25^{\circ} \mathrm{C}$, plated on a 96-well plate, and then reacted with a PGO (glucose oxidase/ peroxidase) enzyme solution (P7119; Sigma-Aldrich, Saint Louis, MO) for 45 min before being read at 450 $\mathrm{nm}$. Neutral- and acid-detergent fiber were analyzed with an Ankom 200 fiber analyzer (Ankom Technology Corp., Macedon, NY) based on the procedures of Van Soest et al. (1991), with a amylase and sodium sulfite in the NDF analysis. A 10-d ruminal incubation was used to analyze indigestible NDF (Huhtanen et al.,
1994, as modified by Lee et al., 2012) in both feces and TMR, which was used as a marker to estimate apparent digestibilities of dietary nutrients.

Enteric $\mathrm{CH}_{4}$ and $\mathrm{CO}_{2}$ emissions were analyzed during wk 4 of each period with the GreenFeed system (C-Lock Inc., Rapid City, SD). Measurements were collected 8 times over $3 \mathrm{~d}$ at 0900, 1500, 2100, 0300, 1200, 1800, 2400 , and $0500 \mathrm{~h}$ to obtain a representative sample of a 24-h period. Gas sampling procedures followed those recommended by Hristov et al. (2015). Gas emission data were averaged by cow and period for the statistical analysis.

\section{In Situ}

Ruminal disappearance of DM (alfalfa haylage, wheat, triticale, and corn silages) and NDF (wheat and triticale silages and alfalfa haylage) was determined in situ. Six ruminally cannulated lactating Holstein cows averaging $24.4 \pm 2.4 \mathrm{~kg} / \mathrm{d}$ of DMI, $36.8 \pm 2.9 \mathrm{~kg} / \mathrm{d}$ of MY, $2.2 \pm 0.4$ lactations, $148 \pm 10$ DIM, and $616 \pm$ $40.7 \mathrm{~kg}$ of BW were used for in situ incubations. Cows were fed (\% DM basis) corn silage 38.3, alfalfa haylage 13.8 , grass hay and straw mixture 4.2 , ground corn 9.6 , canola meal 9.6, cookie meal 5.3, roasted soybeans 5.0, molasses 5.0, whole cotton seed 4.6, cracked corn 2.5, and mineral mix 2.1. Oven-dried forages were ground through a 4-mm screen in a Wiley mill. Approximately $7 \mathrm{~g}$ of sample were weighed into $10 \times 20 \mathrm{~cm}$ nylon bags with 50- $\mu \mathrm{m}$ porosity (Ankom Technology Corp.) and closed with a zip tie after folding. Triplicate bags were sequentially incubated in each cow for $12,24,48,72$, and $96 \mathrm{~h}$ and simultaneously removed. Two bags per forage were made for the 0 -h time point and processed as the incubated samples, except the rumen incubation step. Upon removal from the rumen, the bags were rinsed 3 times with cold water in a washer machine set to agitate for $6 \mathrm{~min}$ each rinse. The zip ties were cutoff and any remaining particles rinsed with cold tap water. Rinsed bags were then oven-dried for $72 \mathrm{~h}$ at $55^{\circ} \mathrm{C}$ before weighing for $\mathrm{DM}$ determination. Samples were composited by silage, time point, and cow before NDF analysis, as previously described. Ruminal disappearance was calculated based on initial dry weight of the incubated sample, residue dry weight, and NDF concentration of initial sample and bag residue. Degradation curves were fit to the equation $p=a+b(1-$ $\mathrm{e}^{-c t}$ ), where $p$ is the degraded fraction (of DM or NDF) at time $t, a$ is the soluble fraction, $b$ is the potentially degradable fraction, and $c$ is the rate of degradation of the $b$ fraction (Ørskov and McDonald, 1979). The effective degradability (ED) was determined with the following equation (Ørskov and McDonald, 1979), ED $=a+b[c /(c+k)]$, where $k$ is the rate of passage 
assumed to be $0.03 / \mathrm{h}$. Corn silage NDF degradability did not fit the Ørskov and McDonald model; thus, it was fit with a linear model. Therefore, corn silage NDF degradability was not statistically compared with the other forages.

\section{IOFC}

Income over feed costs for the 3 diets was calculated using the Pennsylvania State Extension Dairy Team IOFC Tool (Penn State Extension, 2015). The cash flow spreadsheet from the Pennsylvania State Extension Dairy Team (Penn State Extension, 2016) was used to calculate forage monetary values for the IOFC tool. We used a 34.4-ha model dairy farm with 65 lactating cows, 10 dry cows, 52 heifers, and 12 calves. It was assumed that only the forages were grown on the farm, whereas concentrates were purchased. The lactating cow ration was changed in the scenarios to reflect the treatment diet, whereas diets for other cow groups (e.g., dry cows, heifers, and calves) were kept the same among scenarios. First, the total amount of the different forages required for each scenario was calculated. Next, the acres needed to produce that amount was found by dividing the total amount of each crop needed by the per acre crop yields typical for central Pennsylvania. The corn yield for the double-cropped scenarios was decreased by $2.35 \mathrm{t}$ of $\mathrm{DM} /$ ha to account for the lower yield due to delayed corn planting. Then, the variable costs of seed, fertilizer, and herbicide per acre for each crop during 2014 was entered into the spreadsheet. Along with the input costs and the yield information for each crop, the fixed costs were allocated among the forages based on the labor used to produce them to determine price per tonne. Milk and components yield from the current study was used with the average milk pricing in Pennsylvania for 2015 to generate the income side of the IOFC equation.

\section{Statistical Analysis}

Statistical analyses for all but the in situ data were run using the MIXED procedure of SAS version 9.4 (SAS Institute Inc., Cary, NC). Cow was the experimental unit. Milk yield and DMI from the last $10 \mathrm{~d}$ of the experiment were analyzed with day as a repeated measure. The statistical model included day, period, diet, and period $\times$ diet and diet $\times$ day interactions. Square and cow within square were random effects, with all others fixed. Milk composition and FA, nutrient intake, digestibility, $\mathrm{N}$ utilization, $\mathrm{CH}_{4}$, and $\mathrm{CO}_{2}$ emissions data were analyzed using the same model without day and diet $\times$ day interaction. Milk composi- tion data were weighted averages based on the milk production at each milking. Forage nutrient composition was compared using the MIXED procedure with forage type as the model. Significance was declared at $P \leq 0.05$ and tendency was declared at $0.05<P \leq$ 0.10 . If not indicated otherwise, data are presented as least squares means.

Ruminal in situ degradation of DM and NDF was analyzed using the NLMIXED procedure of SAS. The overall regression curve and the individual parameters $(a, b, c$, and $\mathrm{ED})$ were contrasted among forages and significance was declared at $P \leq 0.05$.

\section{RESULTS AND DISCUSSION}

\section{Forages}

Triticale yielded $2.79 \mathrm{t}$ of $\mathrm{DM} /$ ha and wheat yielded $2.57 \mathrm{t}$ of DM/ha. A survey of triticale double cropped with corn in New York reported an average yield of 4.9 t of DM/ha from 2012 to 2014 (Ketterings et al., 2015). Yields could potentially have been increased in the current study by earlier planting in late September and an extra $43 \mathrm{~kg} / \mathrm{ha}$ of $\mathrm{N}$ fertilizer in the spring. The cover crops were harvested at the same growth stage but, due to different maturation patterns, wheat was harvested $5 \mathrm{~d}$ after triticale. From a practical standpoint, different harvest windows can reduce risk and decrease the daily workload during harvest, which can be used to a farmer's advantage. Triticale normally has greater yields than wheat (Giunta et al., 1993; EstradaCampuzano et al., 2012), as was the case in this study. Corn silage varieties had an average yield of $18 \mathrm{t}$ of $\mathrm{DM} /$ ha. Nutrient composition and fermentation data of the 3 silages are presented in Table 2 . The triticale silage fermentation may have benefited from a higher target ensiling DM because of elevated total VFA and lactic acid concentrations along with some butyric acid production. Both silages did reach a final $\mathrm{pH}$ level below 4.5 , but were higher $(P<0.001)$ than the $\mathrm{pH}$ of 3.68 in the corn silage. Titratable acidity followed the pattern of total fermentation acid concentration. Overall, the alternative silages had higher $(P \leq 0.01) \mathrm{NDF}$, ADF, lignin, $\mathrm{CP}$, and soluble $\mathrm{CP}$ as a percent of $\mathrm{CP}$ content than corn silage, whereas starch concentrations were at or below $1 \%$. The lignin content of wheat silage was slightly higher $(P<0.01)$ than triticale silage, whereas $\mathrm{CP}$ was higher $(P<0.001)$ in triticale than wheat silages. Wheat silage had higher $(P<0.001)$ ethanolsoluble carbohydrates than triticale or corn silage.

The simple by-weight replacement of corn silage in our study was chosen to clearly demonstrate how inclusion of wheat or triticale cover crops used as forages in a 
double-cropping strategy might affect cow productivity without other changes on the farm, such as increased corn grain purchases. Previous research with cereal silages have focused on more mature crops in the dough stage when yield and starch content are high (Sutton et al., 2001). However, wheat and triticale must be harvested at the boot stage or earlier to produce highly digestible forage and allow growing season for double cropping with corn silage. At this stage, however, these plants accumulate little to no starch (Fearon et al., 1990; Crovetto et al., 1998).

\section{$D M I$ and $M Y$}

Dry matter intake is known to have a large influence on milk production. In the current study, DMI was not different between diets (Table 3); however, MY was decreased $(P=0.01)$ in TS and WS compared with CS. Arieli and Adin (1994) reported equal DMI but different MY for diets containing wheat silages harvested at flower versus milk stage maturities. Those authors explained the difference in MY by differences in NDF digestibility of the 2 silages, but this would not describe the results of the current study. Sinclair et al. (2005) found an increase in DMI but similar MY comparing urea-treated wheat silage harvested in the dough stage versus corn silage. Hameleers (1998) reported an increase in DMI with corn silage or wheat silage replacing grass silage, but no effect on MY around $27 \mathrm{~kg} / \mathrm{d}$.

Milk yield in the current study was high for all diets but decreased to a similar extent for TS and WS compared with CS. A decrease in feed efficiency has been observed in other experiments utilizing wheat silage (Sutton et al., 1998). The most likely cause of the decreased MY was the replacement of starch with fiber in the alternative forage diets. When these alternative forage cover crops partially replace corn silage in a ration, starch content is decreased and, with it, dietary available energy (Mertens, 2009). This is despite the fact that when the rations where entered into NRC (2001), the $\mathrm{NE}_{\mathrm{L}}$ concentrations were very similar. Ground corn or other starch sources could be added into the ration to compensate for the decreased starch supply from corn silage, but that would likely have to be purchased on most farms. Bernard et al. (2002) replaced corn silage with annual ryegrass silage in lactating cows along with increased ground corn and reported no effect on DMI but an increase in MY. Even at the early harvest date of our study, alternative forages had higher NDF, $\mathrm{ADF}$, and lignin concentrations compared with corn

Table 2. Nutrient composition and fermentation profile of corn, triticale, and wheat silages (\% of DM or as indicated $)^{1}$

\begin{tabular}{|c|c|c|c|c|c|}
\hline \multirow[b]{2}{*}{ Item } & \multicolumn{3}{|c|}{ Forage } & \multirow[b]{2}{*}{$\mathrm{SEM}^{2}$} & \multirow{2}{*}{$\frac{P \text {-value }}{\text { Forage }}$} \\
\hline & Corn & Triticale & Wheat & & \\
\hline $\mathrm{DM}, \%$ & $38.5^{\mathrm{a}}$ & $30.7^{\mathrm{b}}$ & $40.7^{\mathrm{a}}$ & 1.42 & $<0.01$ \\
\hline $\mathrm{NDF}$ & $41.0^{\mathrm{b}}$ & $51.1^{\mathrm{a}}$ & $51.0^{\mathrm{a}}$ & 0.96 & $<0.001$ \\
\hline $\mathrm{ADF}$ & $23.7^{\mathrm{b}}$ & $32.9^{\mathrm{a}}$ & $32.5^{\mathrm{a}}$ & 0.55 & $<0.001$ \\
\hline Lignin & $2.82^{\mathrm{c}}$ & $3.47^{\mathrm{b}}$ & $3.83^{\mathrm{a}}$ & 0.103 & $<0.01$ \\
\hline Fat & 3.38 & 3.89 & 3.57 & 0.281 & 0.48 \\
\hline $\mathrm{CP}$ & $6.4^{\mathrm{c}}$ & $17.3^{\mathrm{a}}$ & $14.6^{\mathrm{b}}$ & 0.32 & $<0.001$ \\
\hline Soluble $\mathrm{CP}, \%$ of $\mathrm{CP}$ & $61.8^{\mathrm{c}}$ & $80.8^{\mathrm{a}}$ & $74.6^{\mathrm{b}}$ & 1.07 & $<0.001$ \\
\hline Starch & $34.5^{\mathrm{a}}$ & $0.3^{\mathrm{b}}$ & $1.0^{\mathrm{b}}$ & 0.96 & $<0.001$ \\
\hline Ethanol-soluble carbohydrates & $1.0^{\mathrm{b}}$ & $2.1^{\mathrm{b}}$ & $4.6^{\mathrm{a}}$ & 0.32 & $<0.001$ \\
\hline Ash & $3.76^{\mathrm{c}}$ & $9.85^{\mathrm{a}}$ & $8.35^{\mathrm{b}}$ & 0.277 & $<0.001$ \\
\hline $\mathrm{Ca}$ & $0.18^{\mathrm{c}}$ & $0.43^{\mathrm{a}}$ & $0.28^{\mathrm{b}}$ & 0.016 & $<0.001$ \\
\hline $\mathrm{P}$ & $0.24^{\mathrm{c}}$ & $0.42^{\mathrm{a}}$ & $0.33^{\mathrm{b}}$ & 0.013 & $<0.001$ \\
\hline $\mathrm{K}$ & $1.06^{\mathrm{c}}$ & $4.34^{\mathrm{a}}$ & $2.99^{\mathrm{b}}$ & 0.077 & $<0.001$ \\
\hline $\mathrm{pH}$ & $3.68^{\mathrm{b}}$ & $4.48^{\mathrm{a}}$ & $4.46^{\mathrm{a}}$ & 0.026 & $<0.001$ \\
\hline \multicolumn{6}{|l|}{ Fermentation acid } \\
\hline Lactic & $4.17^{\mathrm{b}}$ & $7.03^{\mathrm{a}}$ & $6.43^{\mathrm{a}}$ & 0.309 & $<0.01$ \\
\hline Acetic & $1.20^{\mathrm{b}}$ & $3.34^{\mathrm{a}}$ & $2.29^{\mathrm{ab}}$ & 0.435 & 0.04 \\
\hline Propionic & $0.02^{\mathrm{b}}$ & $0.49^{\mathrm{a}}$ & $0.09^{\mathrm{b}}$ & 0.043 & $<0.001$ \\
\hline Butyric & $\mathrm{ND}^{3}$ & 0.85 & ND & - & - \\
\hline Isobutyric & ND & 0.53 & ND & - & - \\
\hline Titratable acidity, mEq/100 g & $5.82^{\mathrm{b}}$ & $8.26^{\mathrm{a}}$ & $5.00^{\mathrm{b}}$ & 0.486 & $<0.01$ \\
\hline
\end{tabular}

${ }^{a-c}$ Means within the same row without a common superscript differ $(P<0.05)$.

${ }^{1}$ Three composite samples per silage, one for each experimental period, were analyzed by wet chemistry (Cumberland Valley Analytical Services Inc., Maugansville, MD). Mean \pm SE is reported.

${ }^{2}$ Largest SEM published in table; $\mathrm{n}=9$ ( $\mathrm{n}$ represents the number of observations used in the statistical analysis).

${ }^{3} \mathrm{ND}=$ not detected. 
silage, possibly causing increased rumen fill. This may have prevented an increase in DMI for the alternative forage diets to maintain milk production.

\section{Milk Composition}

Milk composition was unaffected by diet, which agrees with results from Hameleers (1998) and Sutton et al. (1998), who compared wheat silage to corn and grass silages, respectively. However, those studies were with a high-starch, dough stage wheat silage. O'Mara et al. (1998) likewise found no effect of grass silage versus corn silage though, again, starch content was kept similar across diets. We did observe higher milk protein yield in CS, even with higher RUP levels in TS and WS, which suggests energy was less available for microbial protein synthesis in the rumen with the alternative forage diets. The tendency $(P=0.07)$ for a decrease in the sum of odd- and branched-chain milk FA in TS and WS, compared with corn silage (see below), would also support the expectation of lower milk true protein in those diets; Vlaeminck et al. (2006) showed a positive correlation between odd- and branched-chain milk FA and bacterial $\mathrm{N}$ flow to the duodenum. Despite lower starch and higher fiber intake with the alternative silage diets, compared with the control corn silage diet, milk fat concentration or yield were unaffected.

\section{Milk FA}

Milk FA analysis (Table 4) revealed increased $(P \leq$ $0.004)$ concentrations of de novo-synthesized FA 4:0 and 6:0 for TS and WS compared with CS. Stearic acid (18:0) was also increased $(P=0.008)$ in TS and WS, whereas trans-10 18:1 was increased $(P<0.001)$ in CS with a tendency $(P=0.10)$ for greater total trans FA. Increases in trans-10 18:1 in milk fat have been associated with milk fat depression, albeit at greater concentrations than in the current study (Rico and Harvatine, 2013). Trans-10 18:1 is a ruminal biohydrogenation intermediate from an alternate pathway responsible for decreased de novo milk FA synthesis (Harvatine et al., 2009). The higher $(P \leq 0.04)$ odd-chain FA, 15:0, 17:0, and 17:1, in CS along with the lower iso 14:0 $(P=0.04)$ suggests a lower rumen $\mathrm{pH}$ based on the relationship with SARA reported by Fievez et al. (2012), though we have no direct rumen $\mathrm{pH}$ measurements to confirm these data. The higher fiber and lower starch contents of TS and WS, compared with CS, may have caused differences in ruminal biohydrogenation.

\section{Nutrient Intake and Digestibility}

Intakes of $\mathrm{CP}$ and $\mathrm{ADF}$ were higher $(P \leq 0.01)$ for both TS and WS compared with CS (Table 5). Starch intake was higher $(P<0.001)$ for CS compared with either of the alternative silage diets. These results are an outcome of the higher CP and ADF and lower starch contents in the triticale and wheat silages than in the corn silage and the equal DMI among diets. Apparent total-tract digestibility of $\mathrm{DM}$ and $\mathrm{OM}$ was decreased $(P<0.01)$ in WS, compared with CS, but not in TS. Meanwhile, NDF and ADF digestibility was increased $(P \leq 0.005)$ in TS but not WS. The decreased DM

Table 3. Effect of triticale and wheat silage on DMI, milk production, and feed efficiency in lactating dairy cows

\begin{tabular}{|c|c|c|c|c|c|}
\hline \multirow[b]{2}{*}{ Item } & \multicolumn{3}{|c|}{$\operatorname{Diet}^{1}$} & \multirow[b]{2}{*}{$\mathrm{SEM}^{2}$} & \multirow{2}{*}{$\frac{P \text {-value }}{\text { Diet }}$} \\
\hline & CS & TS & WS & & \\
\hline DMI, kg/d & 27.2 & 27.7 & 27.6 & 1.80 & 0.37 \\
\hline Milk yield, $\mathrm{kg} / \mathrm{d}$ & $42.7^{\mathrm{a}}$ & $41.2^{\mathrm{b}}$ & $41.4^{\mathrm{b}}$ & 5.18 & 0.01 \\
\hline Milk yield/DMI, $\mathrm{kg} / \mathrm{kg}$ & $1.61^{\mathrm{a}}$ & $1.55^{\mathrm{b}}$ & $1.52^{\mathrm{b}}$ & 0.16 & $0.03^{3}$ \\
\hline Milk fat, $\%$ & 3.77 & 3.80 & 3.80 & 0.14 & 0.93 \\
\hline Milk fat, $\mathrm{kg} / \mathrm{d}$ & 1.60 & 1.52 & 1.53 & 0.11 & 0.11 \\
\hline Milk true protein, $\%$ & 2.96 & 2.95 & 2.97 & 0.04 & 0.91 \\
\hline Milk true protein, $\mathrm{kg} / \mathrm{d}$ & $1.27^{\mathrm{a}}$ & $1.20^{\mathrm{b}}$ & $1.20^{\mathrm{b}}$ & 0.10 & 0.02 \\
\hline Lactose, $\%$ & 4.94 & 4.88 & 4.88 & 0.05 & 0.11 \\
\hline Lactose, $\mathrm{kg} / \mathrm{d}$ & $2.14^{\mathrm{a}}$ & $2.00^{\mathrm{b}}$ & $1.98^{\mathrm{b}}$ & 0.17 & 0.008 \\
\hline MUN, mg/dL & $10.8^{\mathrm{b}}$ & $12.7^{\mathrm{a}}$ & $13.1^{\mathrm{a}}$ & 0.53 & $<0.001$ \\
\hline $\mathrm{ECM}^{4}{ }^{4} \mathrm{~kg} / \mathrm{d}$ & $40.9^{\mathrm{a}}$ & $38.6^{\mathrm{b}}$ & $38.5^{\mathrm{b}}$ & 2.97 & 0.05 \\
\hline $\mathrm{BW}, \mathrm{kg}$ & 634 & 629 & 633 & 30.3 & 0.30 \\
\hline
\end{tabular}

${ }_{\mathrm{a}, \mathrm{b}}$ Means within the same row without a common superscript differ $(P \leq 0.05)$.

${ }^{1} \mathrm{CS}=$ corn silage control diet; $\mathrm{TS}=$ triticale silage diet; $\mathrm{WS}=$ wheat silage diet

${ }^{2}$ Largest SEM published in table. DMI, $\mathrm{n}=360$; milk yield, $\mathrm{n}=335$; milk yield/DMI, $\mathrm{n}=335$; $\mathrm{BW}, \mathrm{n}=36$; milk composition data, $\mathrm{n}=36$ ( $\mathrm{n}$ represents the number of observations used in the statistical analysis).

${ }^{3}$ Period $\times$ diet interaction, $P=0.009$.

${ }^{4}$ Energy-corrected milk $(\mathrm{kg} / \mathrm{d})=\mathrm{kg}$ of milk $\times[(38.3 \times \%$ fat $\times 10+24.2 \times \%$ true protein $\times 10+16.54 \times$

$\%$ lactose $\times 10+20.7) / 3,140]$ (Sjaunja et al., 1990). 
Table 4. Effect of triticale and wheat silage on milk fatty acid composition (g/100 g of total fatty acids) in lactating dairy cows

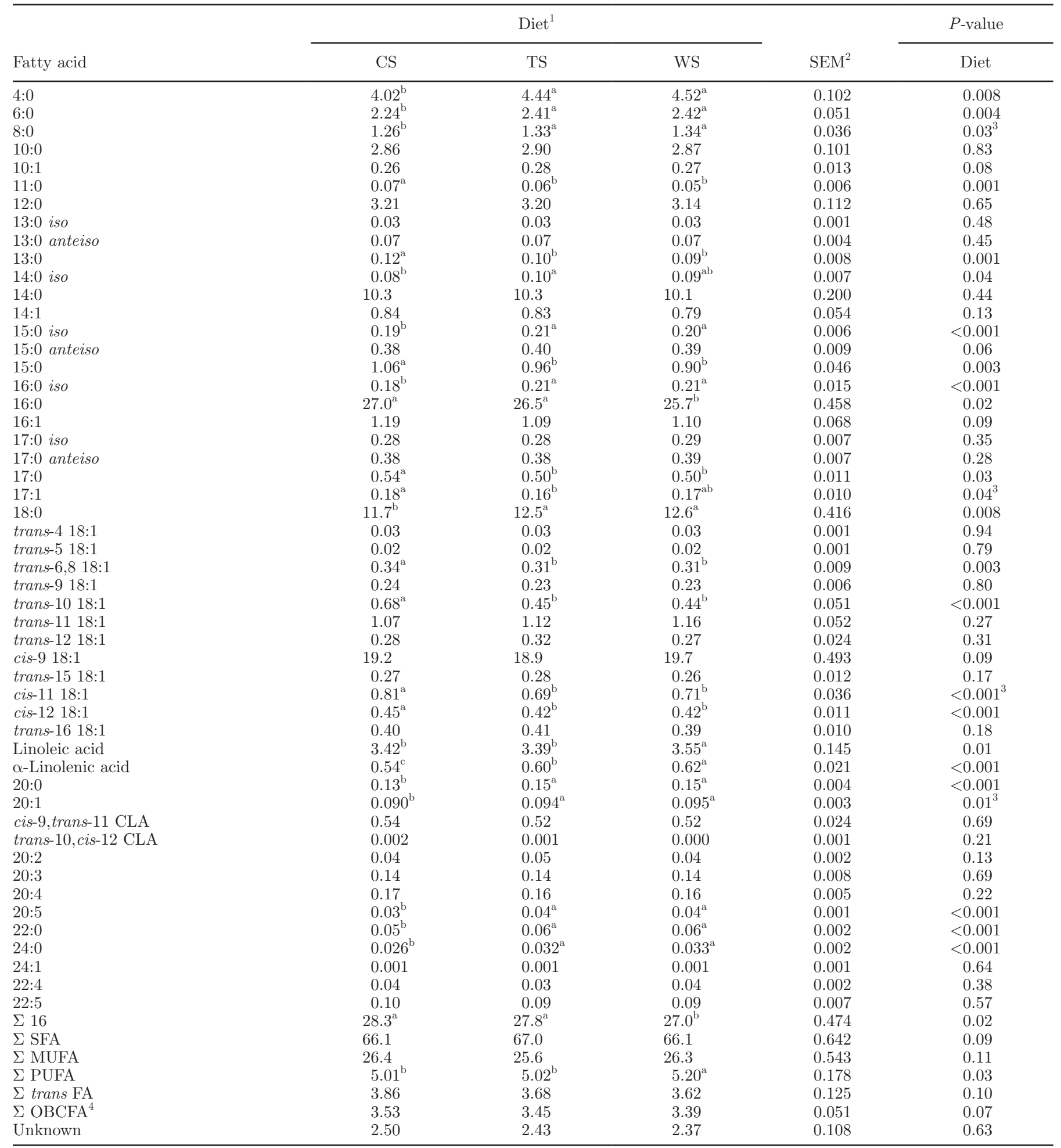

${ }^{\mathrm{a}-\mathrm{c}}$ Means within the same row without a common superscript differ $(P<0.05)$.

${ }^{1} \mathrm{CS}=$ corn silage control diet; TS $=$ triticale silage diet; WS $=$ wheat silage diet.

${ }^{2}$ Largest SEM shown; $\mathrm{n}=36$ ( $\mathrm{n}$ represents number of observations used in the statistical analysis). Data are presented as LSM.

${ }^{3}$ Period $\times$ diet interactions: $8: 0=0.05 ; 17: 1=0.03 ;$ cis-11 18:1 $=0.04 ; 20: 1=0.02$.

${ }^{4}$ Sum of the odd- and branched-chain fatty acids (iso13:0, anteiso13:0, 13:0, iso14:0, iso15:0, anteiso15:0, 15:0, iso16:0, iso17:0, 17:0, 17:1). 
and OM digestibility of WS was likely a result of the lower starch and higher fiber and lignin content in the wheat silage compared with corn silage. The TS diet had lower starch and higher fiber, as WS did, but somewhat surprisingly did not decrease DM or OM digestibility. Likely the lower lignin level in the triticale silage over the wheat silage improved TS digestibility. It has been shown that DM and NDF digestibility are negatively correlated with lignin content (Jung et al., 1997). O'Mara et al. (1998) reported higher diet digestibilities of DM, OM, and NDF but not $\mathrm{N}$ when grass silage replaced corn silage in lactating cow diets, which matched the results of TS in the current experiment. Less starch in TS and WS probably resulted in higher rumen $\mathrm{pH}$ (though it was not measured directly in this experiment), which improves fiber digestibility (Firkins, 1997), although the high lignin in the wheat silage may have counteracted that effect. Starch digestibility was high for all diets, but highest $(P<0.001)$ for CS followed by TS and then WS. The rate of starch digestibility in corn silage is usually high and can be faster than that of fine ground corn (Lanzas et al., 2007). The CS diet had the highest proportion of starch from corn silage, and this was likely the reason for the increased starch digestibility in CS.

\section{In Situ}

In situ DM disappearance curves are shown in Figure 1. Numerical ranking of in situ ED of DM among triti- cale, wheat, and corn silages matches apparent totaltract DM and OM digestibility of TS, WS, and CS. Because of its high starch content and despite its low NDF degradation rate, corn silage still had one of the highest ED of DM along with triticale silage. Wheat silage ED of DM was slightly lower $(P<0.001)$ than triticale and corn silage, but higher $(P<0.001)$ than alfalfa haylage. Although ED of DM was not drastically different among triticale, wheat, and corn silages, the differences in the nutrient composition of the silage DM may have affected cow performance among the experimental diets. The wheat and triticale silage contained higher ash and CP content, whereas corn silage had higher starch content, potentially resulting in more digestible energy for supporting higher milk production in CS.

Ruminal in situ NDF degradability data (Figure 2 ) revealed that triticale silage had the highest $(P<$ 0.001 ) ED of NDF, followed by wheat silage and alfalfa haylage. Triticale is a cross between wheat and rye, therefore, it was expected that the NDF degradability pattern would be similar to wheat. Triticale and wheat silages had nearly identical NDF and ADF contents, but wheat silage had higher lignin concentrations. This appeared to have negatively affected in situ ED of NDF and the DM and OM apparent total-tract digestibilities of WS. It may be that the wheat silage was actually more physiologically mature than the triticale silage, as we harvested the wheat a few days after the triticale even though we targeted the same maturity at harvest.

Table 5. Effect of triticale and wheat silage on nutrient intake and apparent total-tract digestibility in lactating dairy cows

\begin{tabular}{|c|c|c|c|c|c|}
\hline \multirow[b]{2}{*}{ Item } & \multicolumn{3}{|c|}{ Diet $^{1}$} & \multirow[b]{2}{*}{$\mathrm{SEM}^{2}$} & \multirow{2}{*}{$\frac{P \text {-value }}{\text { Diet }}$} \\
\hline & CS & TS & WS & & \\
\hline \multicolumn{6}{|c|}{ Intake, $\mathrm{kg} / \mathrm{d}$} \\
\hline $\mathrm{DM}^{3}$ & 26.6 & 27.0 & 27.2 & 1.53 & 0.62 \\
\hline $\mathrm{OM}$ & 24.8 & 25.0 & 25.2 & 1.42 & 0.76 \\
\hline $\mathrm{CP}$ & $4.28^{\mathrm{b}}$ & $4.65^{\mathrm{a}}$ & $4.60^{\mathrm{a}}$ & 0.26 & 0.006 \\
\hline Starch & $7.33^{\mathrm{a}}$ & $5.77^{\mathrm{b}}$ & $5.62^{\mathrm{b}}$ & 0.36 & $<0.001$ \\
\hline NDF & 8.85 & 9.18 & 9.25 & 0.52 & 0.17 \\
\hline $\mathrm{ADF}$ & $5.61^{\mathrm{b}}$ & $5.99^{\mathrm{a}}$ & $6.01^{\mathrm{a}}$ & 0.33 & 0.01 \\
\hline \multicolumn{6}{|c|}{ Apparent digestibility, \% } \\
\hline $\mathrm{DM}$ & $66.9^{\mathrm{a}}$ & $67.0^{\mathrm{a}}$ & $65.1^{\mathrm{b}}$ & 0.75 & 0.01 \\
\hline $\mathrm{OM}$ & $67.9^{\mathrm{a}}$ & $68.2^{\mathrm{a}}$ & $66.3^{\mathrm{b}}$ & 0.73 & 0.01 \\
\hline $\mathrm{CP}$ & 64.4 & 65.0 & 63.0 & 1.04 & 0.14 \\
\hline Starch & $99.5^{\mathrm{a}}$ & $99.3^{\mathrm{b}}$ & $99.1^{\mathrm{c}}$ & 0.05 & $<0.001$ \\
\hline NDF & $44.2^{\mathrm{b}}$ & $47.0^{\mathrm{a}}$ & $42.9^{\mathrm{b}}$ & 1.07 & 0.005 \\
\hline $\mathrm{ADF}$ & $37.1^{\mathrm{b}}$ & $41.9^{\mathrm{a}}$ & $36.8^{\mathrm{b}}$ & 1.27 & 0.003 \\
\hline
\end{tabular}


Corn silage NDF degradability data did not fit the Orskov and McDonald model, but it did fit to a linear model with a rate of $0.57 \% / \mathrm{h}$ and a coefficient of determination of 0.94 . Filya (2003) reported corn silage in situ NDF degradability values at $48 \mathrm{~h}$ of approximately $22.4 \%$, which is similar to our $28.6 \%$ value. For triticale or wheat silage at the boot stage to successfully replace part of the corn silage in a lactating cow diet, NDF degradability has to be high, as it is the main source of energy in these silages.

\section{N Utilization}

Both TS and WS had a similar effect on $\mathrm{N}$ utilization (Table 6), with higher $(P=0.006) \mathrm{N}$ intake than CS. Cows fed TS and WS excreted more urinary urea $\mathrm{N}(P$ $=0.001)$ and total excreta $\mathrm{N}(P=0.006)$ while having a tendency $(P=0.08)$ for less $\mathrm{N}$ secreted in milk than CS. Together, this led to a lower $(P=0.005)$ milk N efficiency for TS and WS, compared with CS. Hameleers (1998) also reported a decrease in milk N efficiency when grass silage was replaced with urea-treated wheat silage. Similar to that experiment, we formulated our CS diet to meet MP requirements for the level of production of the cows and did not adjust protein content of the alternative forage diets. Therefore, TS and

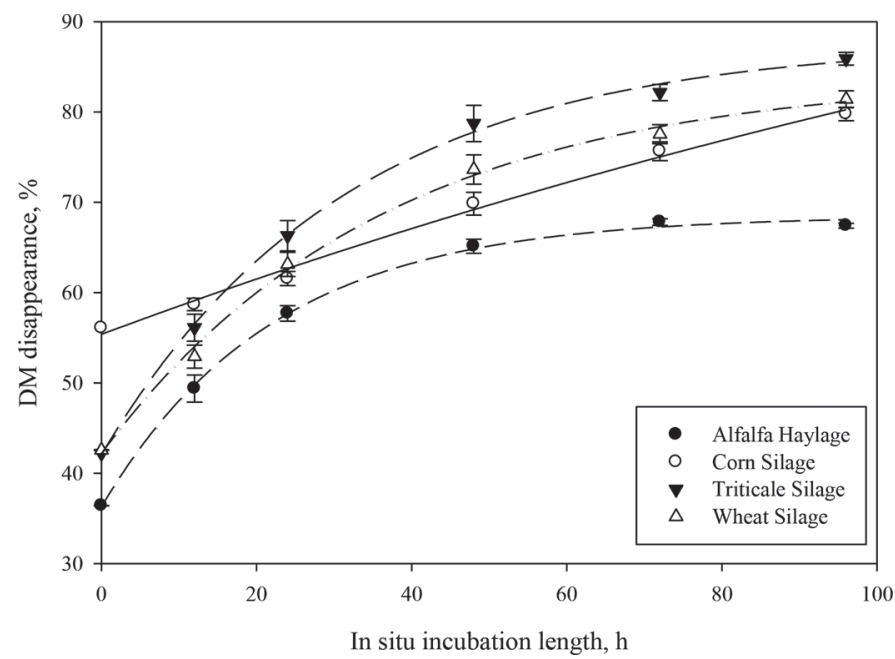

Figure 1. Ruminal in situ DM disappearance of forage sources. Data are means $\pm \mathrm{SE}(\mathrm{n}=6)$. Disappearance curves were fit using SigmaPlot 10.0 (Systat Software, Chicago, IL) to the equation $p=a$ $+b\left(1-\mathrm{e}^{-c t}\right.$ ), where $p$ is the degraded fraction (of DM) at time $t, a$ is the soluble fraction, $b$ is the potentially degradable fraction, and $c$ is the rate of degradation of the $b$ fraction (Ørskov and McDonald, 1979). Effective degradability (ED) was estimated as $\mathrm{ED}=a+b[c /(c+k)]$, where $a, b, c$, and $p$ are as above and $k$ is the rate of passage (Ørskov and McDonald, 1979), assumed to be $0.03 / \mathrm{h}$ in this study. The ED (model estimates $\pm \mathrm{SE}$ ) for alfalfa haylage was $55.7 \pm 0.48$; corn silage was $64.3 \pm 0.46$; triticale silage was $65.3 \pm 0.49$; and wheat silage was $62.0 \pm 0.48 ;$ means differed $(P<0.05)$.
WS supplied excess $\mathrm{CP}$ as a result of the higher $\mathrm{CP}$ content of the wheat and triticale silages, which was not used but mainly excreted in urine as urea. This presents an opportunity to reduce purchased protein feeds and thereby reduce feed costs in the TS and WS diets (O'Mara et al., 1998; Bernard et al., 2002). Purine derivatives excretion in urine, which is an indication of microbial protein flow to the intestine (Chen, 1989), was not different among treatments.

\section{Enteric $\mathrm{CH}_{4}$ and $\mathrm{CO}_{2}$ Emissions}

Enteric $\mathrm{CH}_{4}$ production was not different among diets (Table 7). Methane yield (i.e., per kg of DMI) or intensity (i.e., per $\mathrm{kg}$ of $\mathrm{MY}$ ) were also not different among diets; however, when calculating $\mathrm{CH}_{4}$ intensity per kilogram of ECM, CS yielded significantly less $(P$ $=0.04) \mathrm{CH}_{4}$ than TS. Increasing starch in a diet favors propionate production and thereby usually reduces $\mathrm{CH}_{4}$ production (Moe and Tyrrell, 1979; Moss et al., 2000), though there have been reports of increased $\mathrm{CH}_{4}$ production with increased dietary starch (Beever et al., 1988). Decreased $\mathrm{CH}_{4}$ yield in beef cattle was clearly demonstrated by Mc Geough et al. (2010) when wholecrop wheat silage diets of increasing grain (i.e., starch) contents were fed. Higher starch in CS was likely the

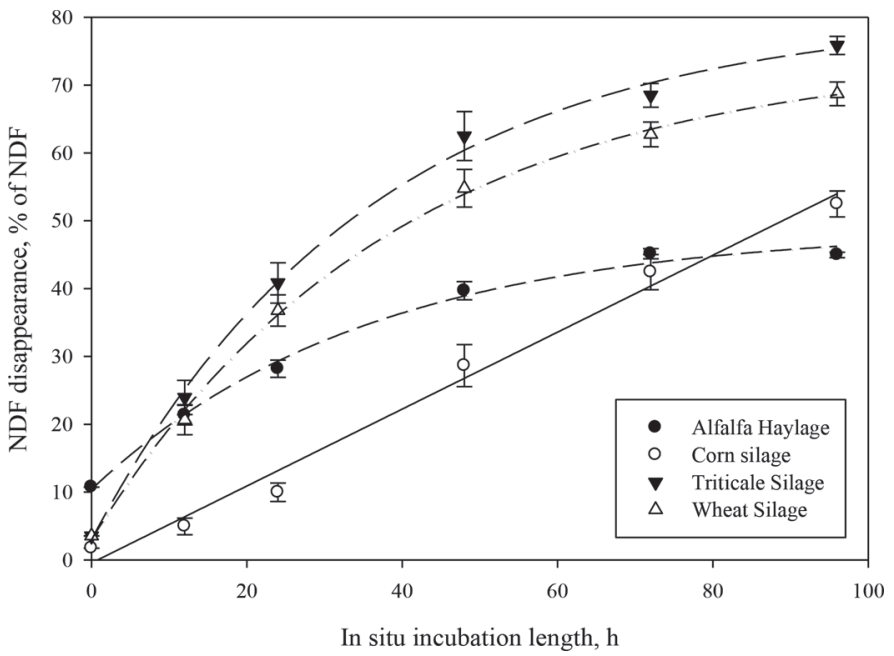

Figure 2. Ruminal in situ NDF disappearance of forage sources. Data are means $\pm \mathrm{SE}(\mathrm{n}=6)$. Disappearance curves of alfalfa haylage, triticale silage, and wheat silage were fit using SigmaPlot 10.0 (Systat Software, Chicago, IL) to the equation $p=a+b\left(1-\mathrm{e}^{-c t}\right)$, where $p$ is the degraded fraction (of NDF) at time $t, a$ is the soluble fraction, $b$ is the potentially degradable fraction, and $c$ is the rate of degradation of the $b$ fraction (Ørskov and McDonald, 1979). Corn silage degradation data were fit to a linear model with an $\mathrm{R}^{2}=0.94$. Effective degradability (ED) was estimated as $\mathrm{ED}=a+b[c /(c+k)]$, where $a, b, c$, and $p$ are as above and $k$ is the rate of passage (Ørskov and McDonald, 1979 ), assumed to be $0.03 / \mathrm{h}$ in this study. The ED (model estimates \pm $\mathrm{SE}$ ) for alfalfa haylage was $29.0 \pm 0.78$; triticale silage was $40.8 \pm 0.78$; and wheat silage was $36.1 \pm 0.78$; means differed $(P<0.05)$. 
cause of the lower enteric $\mathrm{CH}_{4}$ emission intensity per kilogram of ECM. The enteric $\mathrm{CH}_{4}$ yield and intensity values we reported, of around $17.5 \mathrm{~g} / \mathrm{kg}$ of DMI and 12 $\mathrm{g} / \mathrm{kg}$ of MY, are similar to data from our Penn State dairy herd (Hristov et al., 2015) and others (Colombini et al., 2015). Carbon dioxide emissions were decreased $(P=0.006)$ by WS and TS. Kirchgessner et al. (1991) reported a relationship of $\mathrm{CO}_{2}$ emissions to $\mathrm{MY}$ of 0.14 $\mathrm{kg}$ of $\mathrm{CO}_{2} / \mathrm{d}$ for every kilogram of milk produced. Using this relationship, a decrease of around $0.2 \mathrm{~kg}$ of $\mathrm{CO}_{2} / \mathrm{d}$ would have been expected for the current study, yet a $0.6 \mathrm{~kg}$ of $\mathrm{CO}_{2} / \mathrm{d}$ decrease in emissions was measured; however, the direction of the effect was in agreement with the findings of Kirchgessner et al. (1991). Kinsman et al. (1995) also reported a strong correlation between $\mathrm{CO}_{2}$ emissions and milk production $(\mathrm{r}=0.74$; $P<0.001)$. Those authors noted that $\mathrm{CO}_{2}$ production is primarily from cellular respiration of the cow and only secondarily from ruminal fermentation. Some interest exists in using the ratio of enteric $\mathrm{CH}_{4}$ emission to $\mathrm{CO}_{2}$ emission as a way to measure feed efficiency (Madsen et al., 2010). Lower values would indicate less $\mathrm{CH}_{4}$ production and more complete metabolization of $\mathrm{C}$ to $\mathrm{CO}_{2}$ (Madsen et al., 2010). Ratios reported for this study are lowest $(P<0.01)$ for $\mathrm{CS}$ and not different between TS and WS, indicating CS may have been a more completely metabolizable diet in the rumen.

\section{IOFC}

The IOFC of CS was $\$ 11.05$ and decreased to $\$ 10.39$ and $\$ 10.26$ for WS and TS, respectively. Decreased perhectare corn silage yield due to later corn planting and decreased MY caused the decrease in IOFC for WS and TS. The higher IOFC for WS over TS was due to the numerically higher milk and milk fat yield resulting in higher calculated income. The WS and TS diets were not least cost formulations and did not fully use the protein value of the alternative forages, as indicated by the higher MUN and urinary urea nitrogen losses. Likely, the supplemental protein content of WS and TS could be decreased to lower costs of on-farm rations.

\section{CONCLUSIONS}

We demonstrated that triticale and wheat cover crops harvested as silage at the boot stage can support MY above $41 \mathrm{~kg} / \mathrm{d}$ when included at $10 \%$ of the diet DM replacing corn silage. Triticale and wheat silage inclusion did not affect DMI but decreased MY compared with corn silage, likely due to replacing starch with fiber. Higher $\mathrm{CP}$ content in the alternative forages along with lower starch resulted in higher urinary urea excretion, higher MUN concentration, and lower milk $\mathrm{N}$ efficiency. Enteric $\mathrm{CH}_{4}$ emission per kilogram of

Table 6. Effect of triticale and wheat silage on nitrogen utilization and urinary purine derivatives in lactating dairy cows

\begin{tabular}{|c|c|c|c|c|c|}
\hline \multirow[b]{2}{*}{ Item } & \multicolumn{3}{|c|}{ Diet $^{1}$} & \multirow[b]{2}{*}{$\mathrm{SEM}^{2}$} & \multirow{2}{*}{$\frac{P \text {-value }}{\text { Diet }}$} \\
\hline & CS & TS & WS & & \\
\hline $\mathrm{N}$ intake, $\mathrm{g} / \mathrm{d}$ & $685^{\mathrm{b}}$ & $743^{\mathrm{a}}$ & $736^{\mathrm{a}}$ & 40.9 & 0.006 \\
\hline $\mathrm{N}$ excretion or secretion, $\mathrm{g} / \mathrm{d}$ & $594^{\mathrm{b}}$ & $639^{\mathrm{a}}$ & $633^{\mathrm{a}}$ & 38.2 & 0.03 \\
\hline Urine $\mathrm{N}, \mathrm{g} / \mathrm{d}$ & $157^{\mathrm{b}}$ & $191^{\mathrm{a}}$ & $173^{\mathrm{ab}}$ & 12.7 & 0.009 \\
\hline Urinary urea $\mathrm{N}, \mathrm{g} / \mathrm{d}$ & $121^{\mathrm{b}}$ & $157^{\mathrm{a}}$ & $155^{\mathrm{a}}$ & 11.0 & 0.001 \\
\hline Fecal N, g/d & $241^{\mathrm{b}}$ & $261^{\mathrm{ab}}$ & $275^{\mathrm{a}}$ & 15.7 & $0.01^{3}$ \\
\hline Total excreta N, g/d & $398^{\mathrm{b}}$ & $452^{\mathrm{a}}$ & $447^{\mathrm{a}}$ & 25.2 & 0.006 \\
\hline Milk $N, g / d$ & 196 & 188 & 186 & 15.7 & 0.08 \\
\hline \multicolumn{6}{|c|}{$\mathrm{N}$ excretion or secretion, as $\%$ of $\mathrm{N}$ intake } \\
\hline Urine $\mathrm{N}$ & 23.8 & 26.6 & 24.4 & 1.7 & 0.15 \\
\hline Fecal N & 35.6 & 34.9 & 37.3 & 1.05 & 0.08 \\
\hline Total excreta $\mathrm{N}$ & 59.4 & 61.5 & 61.7 & 2.51 & 0.49 \\
\hline Milk N & $29.4^{\mathrm{a}}$ & $26.4^{\mathrm{b}}$ & $26.2^{\mathrm{b}}$ & 2.21 & 0.005 \\
\hline Urine output ${ }^{4} \mathrm{~kg} / \mathrm{d}$ & $17.9^{\mathrm{b}}$ & $23.5^{\mathrm{a}}$ & $22.4^{\mathrm{a}}$ & 2.13 & 0.03 \\
\hline \multicolumn{6}{|l|}{ Urinary $\mathrm{PD}^{5}$ excretion, $\mathrm{mmol} / \mathrm{d}$} \\
\hline Allantion & 452 & 502 & 493 & 48.0 & 0.61 \\
\hline Uric acid & 65.4 & 68.4 & 67.7 & 6.72 & 0.87 \\
\hline Total PD & 517 & 571 & 561 & 53.3 & 0.62 \\
\hline
\end{tabular}

${ }_{\mathrm{a}, \mathrm{b}}$ Means within the same row without a common superscript differ $(P<0.05)$.

${ }^{1} \mathrm{CS}=$ corn silage control diet; $\mathrm{TS}=$ triticale silage diet; $\mathrm{WS}=$ wheat silage diet.

${ }^{2}$ Largest SEM published in table; $\mathrm{n}=36$ ( $\mathrm{n}$ represents the number of observations used in the statistical analysis).

${ }^{3}$ Period $\times$ diet interaction, $P=0.04$.

${ }^{4}$ Estimated from urine creatinine concentration, assumed to be excreted at $29 \mathrm{mg} / \mathrm{kg}$ of BW.

${ }^{5} \mathrm{PD}=$ purine derivatives. 
Table 7. Effect of triticale and wheat silage on $\mathrm{CO}_{2}$ and $\mathrm{CH}_{4}$ emissions ${ }^{1}$ in lactating dairy cows

\begin{tabular}{|c|c|c|c|c|c|}
\hline \multirow[b]{2}{*}{ Item } & \multicolumn{3}{|c|}{ Diet $^{2}$} & \multirow[b]{2}{*}{$\mathrm{SEM}^{3}$} & \multirow{2}{*}{$\frac{P \text {-value }}{\text { Diet }}$} \\
\hline & CS & TS & WS & & \\
\hline $\mathrm{CO}_{2} \mathrm{~kg} / \mathrm{d}$ & $13.5^{\mathrm{a}}$ & $12.9^{\mathrm{b}}$ & $12.8^{\mathrm{b}}$ & 0.57 & 0.006 \\
\hline $\mathrm{CH}_{4}, \mathrm{~g} / \mathrm{d}$ & 455 & 491 & 463 & 23.4 & 0.16 \\
\hline $\mathrm{CH}_{4}, 4 \mathrm{~g} / \mathrm{kg}$ of DMI & 16.7 & 18.0 & 17.2 & 0.91 & 0.21 \\
\hline $\mathrm{CH}_{4}, 4 \mathrm{~g} / \mathrm{kg}$ of milk yield & 11.6 & 12.3 & 12.0 & 1.03 & 0.61 \\
\hline $\mathrm{CH}_{4}, \mathrm{~g} / \mathrm{kg}$ of ECM & $11.7^{\mathrm{b}}$ & $13.0^{\mathrm{a}}$ & $12.5^{\mathrm{ab}}$ & 0.74 & 0.04 \\
\hline $\mathrm{CH}_{4} / \mathrm{CO}_{2}, \mathrm{~g} / \mathrm{kg}$ & $33.8^{\mathrm{b}}$ & $38.1^{\mathrm{a}}$ & $36.2^{\mathrm{a}}$ & 0.88 & 0.005 \\
\hline
\end{tabular}

$\overline{\mathrm{a}, \mathrm{b}}$ Means within the same row without a common superscript differ $(P<0.05)$.

${ }^{1}$ Rumen gas emissions were measured using GreenFeed (C-Lock Technology Inc., Rapid City, SD). Data were derived from 8 individual measurements staggered over a 3 -d period.

${ }^{2} \mathrm{CS}=$ corn silage control diet; $\mathrm{TS}=$ triticale silage diet; $\mathrm{WS}=$ wheat silage diet.

${ }^{3}$ Largest SEM published in table; $\mathrm{n}=36$ ( $\mathrm{n}$ represents the number of observations used in the statistical analysis).

${ }^{4}$ Based on milk yield and DMI data during the sampling periods.

ECM was increased by TS. Triticale silage had higher in situ effective degradability of NDF and a slightly higher crop yield than wheat silage, although IOFC was slightly more favorable for wheat silage due to numerically higher MY and true milk protein content. Both alternative forages provide a highly digestible source of fiber that can successfully replace corn silage at low inclusion rates. For dairy farms in need of more forage, triticale or wheat double-cropped with corn silage may be an appropriate cropping strategy.

\section{ACKNOWLEDGMENTS}

This project was supported by the Northeast Sustainable Agriculture Research and Education (SARE) program. SARE is a program of the National Institute of Food and Agriculture, USDA (Washington, DC). The authors thank the staff of Farm Operations and Services of the Pennsylvania State University for growing and harvesting the crops fed in our experiment. We also thank the staff of the Pennsylvania State University's Dairy Teaching and Research Center for their conscientious care of the experimental cows. Additionally, we thank Virginia Ishler (Penn State University, University Park) for her help with the IOFC analysis.

\section{REFERENCES}

Arieli, A., and G. Adin. 1994. Effect of wheat silage maturity on digestion and milk yield in dairy cows. J. Dairy Sci. 77:237-243.

Ashbell, G., Z. G. Weinberg, I. Bruckental, K. Tabori, and N. Sharet. 1997. Wheat silage: Effect of cultivar and stage of maturity on yield and degradability in situ. J. Agric. Food Chem. 45:709-712.

Beever, D. E., S. B. Cammell, C. Thomas, M. C. Spooner, M. J. Haines, and D. L. Gale. 1988. The effect of date of cut and barley substitution on gain and on the efficiency of utilization of grass silage by growing cattle 2 . Nutrient supply and energy partition. Br. J. Nutr. 60:307-319.

Bernard, J. K., J. W. West, and D. S. Trammell. 2002. Effect of replacing corn silage with annual ryegrass silage on nutrient digest- ibility, intake, and milk yield for lactating dairy cows. J. Dairy Sci. 85:2277-2282.

Carey, P. L., K. C. Cameron, H. J. Di, G. R. Edwards, and D. F Chapman. 2016. Sowing a winter catch crop can reduce nitrate leaching losses from winter-applied urine under simulated forage grazing: A lysimeter study. Soil Use Manag. 32:329-337.

Chen, X. B. 1989. Excretion of purine derivatives by cattle and sheep and its use for the estimation of absorbed microbial protein. PhD Dissertation. The Rowett Research Institute, Aberdeen University, Aberdeen, UK.

Chen, X. B., Y. K. Chen, M. F. Franklin, E. R. Ørskov, and W. J. Shand. 1992. The effect of feed intake and body weight on purine derivative excretion and microbial protein supply in sheep. J. Anim. Sci. 70:1534-1542.

Colombini, S., M. Zucali, L. Rapetti, G. M. Crovetto, A. Sandrucci, and L. Bava. 2015. Substitution of corn silage with sorghum silages in lactating cow diets: In vivo methane emission and global warming potential of milk production. Agric. Syst. 136:106-113.

Crovetto, G. M., G. Galassi, L. Rapetti, A. Sandrucci, and A. Tamburini. 1998. Effect of the stage of maturity on the nutritive value of whole crop wheat silage. Livest. Prod. Sci. 55:21-32.

Di, H. J., and K. C. Cameron. 2002. Nitrate leaching in temperate agroecosystems: Sources, factors and mitigating strategies. Nutr. Cycl. Agroecosyst. 64:237-256.

Estrada-Campuzano, G., G. A. Salfer, and D. J. Miralles. 2012. Differences in yield, biomass and their components between triticale and wheat grown under contrasting water and nitrogen environments. Field Crops Res. 128:167-179.

Fearon, A. L., A. Felix, and V. T. Sapra. 1990. Chemical composition and in vitro dry matter and organic matter digestibility of triticale forage. J. Agron. Crop Sci. 164:262-270.

Fievez, V., E. Colman, J. M. Castro-Montoya, I. Stefanov, and B. Vlaeminck. 2012. Milk odd- and branched-chain fatty acids as biomarkers of rumen function-An update. Anim. Feed Sci. Technol. 172:51-65.

Filya, I. 2003. The effect of Lactobacillus buchneri, with or without homofermentative lactic acid bacteria, on the fermentation, aerobic stability and ruminal degradability of wheat, sorghum and maize silage. J. Appl. Microbiol. 95:1080-1086.

Firkins, J. L. 1997. Effects of feeding nonforage fiber sources on site of fiber digestion. J. Dairy Sci. 80:1426-1437.

Giunta, F., R. Motzo, and M. Deidda. 1993. Effect of drought on yield and yield components of durum wheat and triticale in a Mediterranean environment. Field Crops Res. 33:399-409.

Hall, M. B. 2009. Determination of starch, including maltooligosaccharides, in animal feeds: Comparison of methods and a method recommended for AOAC collaborative study. J. AOAC Int. 92:42-49.

Hameleers, A. 1998. The effects of the inclusion of either maize silage, fermented whole crop wheat or urea-treated whole crop wheat in 
a diet based on a high-quality grass silage on the performance of dairy cows. Grass Forage Sci. 53:157-163.

Harvatine, K. J., Y. R. Boisclair, and D. E. Bauman. 2009. Recent advances in the regulation of milk fat synthesis. Animal 3:40-54.

Hristov, A. N., J. Oh, F. Giallongo, T. W. Frederick, M. T. Harper, H L. Weeks, A. F. Branco, P. J. Moate, M. H. Deighton, S. Richard, O. Williams, M. Kindermann, and S. Duval. 2015. An inhibitor persistently decreased enteric methane emission from dairy cows with no negative effect on milk production. Proc. Natl. Acad. Sci. USA 112:10663-10668.

Huhtanen, P., K. Kaustell, and S. Jaakkola. 1994. The use of internal markers to predict total digestibility and duodenal flow of nutrients in cattle given six different diets. Anim. Feed Sci. Technol. 48:211-227.

Jung, H. G., D. R. Mertens, and A. J. Payne. 1997. Correlation of acid detergent lignin and klason lignin with digestibility of forage dry matter and neutral detergent fiber. J. Dairy Sci. 80:1622-1628.

Ketterings, Q. M., S. Ort, S. N. Swink, G. Godwin, T. Kilcer, J. Miller, and W. Verbeten. 2015. Winter cereals as double crops in corn rotations on New York dairy farms. J. Agric. Sci. 7:18-25.

Khorasani, G. R., P. E. Jedel, J. H. Helm, and J. J. Kennelly. 1997. Influence of stage of maturity on yield components and chemical composition of cereal grain silages. Can. J. Anim. Sci. 77:259-267.

Khorasani, G. R., E. K. Okine, J. J. Kennelly, and J. H. Helm. 1993. Effect of whole crop cereal grain silage substituted for alfalfa silage on performance of lactating dairy cows. J. Dairy Sci. 76:3536-3546.

Kinsman, R., F. D. Sauer, H. A. Jackson, and M. S. Wolynetz. 1995. Methane and carbon dioxide emissions from dairy cows in full lactation monitored over a six-month period. J. Dairy Sci. 78:27602766 .

Kirchgessner, M., W. Windisch, H. L. Muller, and M. Kreuzer. 1991 Release of methane and of carbon dioxide by dairy cattle. Agribiol. Res. 44:91-102.

Lanzas, C. . C. J. Sniffen, S. Seo, L. O. Tedeschi, and D. G. Fox. 2007. A revised CNCPS feed carbohydrate fractionation scheme for formulating rations for ruminants. Anim. Feed Sci. Technol. 136:167-190

Lee, C., A. N. Hristov, T. W. Cassidy, K. S. Heyler, H. Lapierre, G. A. Varga, M. J. de Veth, R. A. Patton, and C. Parys. 2012. Rumenprotected lysine, methionine, and histidine increase milk protein yield in dairy cows fed a metabolizable protein-deficient diet. J. Dairy Sci. 95:6042-6056.

Madsen, J., B. S. Bjerg, T. Hvelplund, M. R. Weisbjerg, and P. Lund. 2010. Short communication: Methane and carbon dioxide ratio in excreted air for quantification of the methane production from ruminants. Livest. Sci. 129:223-227.

Mc Geough, E. J., P. O'Kiely, K. J. Hart, A. P. Moloney, T. M. Boland, and D. A. Kenny. 2010. Methane emissions, feed intake, performance, digestibility, and rumen fermentation of finishing beef cattle offered whole-crop wheat silages differing in grain content. J. Anim. Sci. 88:2703-2716.

Mertens, D. R. 2009. Impact of NDF content and digestibility on dairy cow performance. Pages 191-201 in Proc. 27th Annual Western
Canadian Dairy Seminar. Red Deer, Alberta. University of Alberta, Edmonton, Alberta, Canada.

Moe, P. W., and H. F. Tyrrell. 1979. Methane production in dairy cows. J. Dairy Sci. 62:1583-1586.

Moss, A. R., J. Jouany, and J. Newbold. 2000. Methane production by ruminants: Its contribution to global warming. Ann. Zootech. 49:231-253.

NRC. 2001. Nutrient Requirements of Dairy Cattle. 7th rev. ed. Natl. Acad. Press, Washington, DC.

O'Mara, F. P., J. J. Fitzgerald, J. J. Murphy, and M. Rath. 1998. The effect on milk production of replacing grass silage with maize silage in the diet of dairy cows. Livest. Prod. Sci. 55:79-87.

Ørskov, E. R., and I. McDonald. 1979. The estimation of protein degradability in the rumen from incubation measurements weighted according to rate of passage. J. Agric. Sci. (Camb.) 92:499-503.

Penn State Extension, 2015. Income over feed cost. Accessed Oct. 10, 2016. http://extension.psu.edu/animals/dairy/ businessmanagement/financial-tools/income-over-feed-cost.

Penn State Extension, 2016. Cash flow spreadsheet. Accessed Oct. 10, 2016. http://extension.psu.edu/animals/dairy/ businessmanagement/financial-tools/cash-flow-planning.

PSU. 2015. The Penn State Agronomy Guide. The Pennsylvania State University, University Park.

Rico, D. E., and K. J. Harvatine. 2013. Induction of and recovery from milk fat depression occurs progressively in dairy cows switched between diets that differ in fiber and oil concentration. J. Dairy Sci. 96:6621-6630.

Shepherd, M. A. 1999. The effectiveness of cover crops during eight years of a UK sandland rotation. Soil Use Manage. 15:41-48.

Sinclair, L. A., M. A. Jackson, J. A. Huntington, and R. J. Readman. 2005. The effects of processed, urea-treated whole-crop wheat or maize silage and supplementation of whole-crop wheat on the performance of dairy cows. Livest. Prod. Sci. 95:1-10.

Sjaunja, L. O., L. Baevre, L. Junkkarinen, J. Pedersen, and J. Setälä. 1990. A Nordic proposal for an energy corrected milk (ECM) formula. Pages 156-157 in Proc. 27th Session Int. Comm. Breeding Product. Milk Anim., Paris, France. Wageningen Acad. Publ., Wageningen, the Netherlands.

Sutton, J. D., S. B. Cammell, D. E. Beever, D. J. Humphries, and R. H. Phipps. 1998. Energy and nitrogen balance of lactating dairy cows given mixtures of urea-treated whole-crop wheat and grass silage. Anim. Sci. 67:203-212.

Sutton, J. D., R. H. Phipps, S. B. Cammell, and D. J. Humphries. 2001. Attempts to improve the utilization of urea-treated wholecrop wheat by lactating dairy cows. Anim. Sci. 73:137-147.

Van Soest, P. J., J. B. Robertson, and B. A. Lewis. 1991. Methods for dietary fiber, neutral detergent fiber, and nonstarch polysaccharides in relation to animal nutrition. J. Dairy Sci. 74:3583-3597.

Vlaeminck, B., V. Fievez, A. R. J. Cabrita, A. J. M. Fonseca, and R. J. Dewhurst. 2006. Factors affecting odd- and branched-chain fatty acids in milk: A review. Anim. Feed Sci. Technol. 131:389-417. 